UNRAM Law Review is licensed under a Creative Commons Attribution 4.0 International License, which permits unrestricted use, distribution, and reproduction in any medium, provided the original work is properly cited. p-ISSN: 2548-9267 | e-ISSN : 2549-2365, Open Access at : http://unramlawreview.unram.ac.id/index.php/ulr

\begin{tabular}{c|c|c|c|c|}
\hline Volume & Issue & Page & Oktober & p-ISSN: 2548-9267 \\
\hline 3 & 2 & $100-107$ & 2019 & e-ISSN : 2549-2365
\end{tabular}

\title{
Legal Politics Of Corporate Responsibility In Indonesia's Criminal Law
}

\author{
Abdul Muflihun \\ Study Programme Magister of Law \\ Universitas Mataram \\ Email: abdulmuflihun@gmail.com \\ Abdul Patah Muzakir \\ Study Programme Magister of Law \\ Universitas Mataram \\ Email: abdulpatahmuzakir@gmail.com \\ Yudi Permana Saputra \\ Study Programme Magister of Law \\ Universitas Mataram \\ Email: bellow_lupher@yahoo.co.id \\ Wawan Septiawan \\ Study Programme Magister of Law \\ Universitas Mataram \\ Email: wawansepiawan0109@gmail.com
}

\begin{abstract}
The purposes of this research are to know the decision public policy by the governmentrelated corporate responsibility in Indonesia's Criminal Law, to know the corporate responsibility special laws in Indonesia, and also the mechanism to find out the corporate's fault. The applied method in this research is normative-legal research. From the research result, it can be concluded that the Government of the Republic of Indonesia has to determine the latest version of Indonesia's Criminal Law or revised several laws related to corporate criminal responsibility. In Indonesia's Criminal Law, corporate criminal responsibility is not recognized, but the corporate responsibility is dispersed in special laws such as Law on Economy Crimes and Consumer Protection. To determined the corporate fault was taken from the manager or member of Board of Directors.
\end{abstract}

Keywords: Corporate; Responsibility; Fault.

\section{INTRODUCTION}

The raised of modernization since the invention of communication, transportation, and modern information, demanded the new values and norms within a state or between the states. The economic sector plays a major role in pushing globalization with the increased of information, money, and multinationals company, which moves swiftly through the free market, capital flows and foreign investment. Globalization 
is not facultative (it is not optional). Globalization not longer as a "that phenomena" but "this phenomena". ${ }^{1}$

Besides, bring advantage for the human being, globalization also brought a new problem, such as the latest economic crime. A fast social mobility caused security system problem, complexity in marketing and distributing. The abundant prosperity influenced people to protect their properties since the technology advances caused high technology-based crime such as cyber crime, counterfeiting money and credit card, and various advances crimes, which has no previous precedent. ${ }^{2}$

Globalization promotes the role of corporate as an actor in several new crimes. Such as pricefixing, false advertising (in pharmaceutical company), environment crimes, banking crimes, cyber crime, money laundering, and illegal logging. ${ }^{3}$ Crimes committed by corporations, the impact of the crime is detrimental to certain communities in an area or even the country could be the victims, for example, is drugs, environment, etc.

In Indonesia's Penal Code (KUHP), corporate as the subject of crimes is not recognized, as concluded in Article 59 KUHP. Legal subject that recognized in KUHP is only man. Argumentation on legal entity/corporation could be act as human, is not known in KUHP.

The legal problem on corporate status as a criminal subject is determination of the fault regarding a crime committed by a corporation, how to determinate a mistake or culpa. In the case of a criminal offense committed by a corporation, determinate a mistakes in the corporation is considered that the subject of this law is different to man as law subject, namely in the case of the presence or absence of mistakes (deliberate / negligence), which is usually this error generally found in humans. Mistakes are one of the basic legal subjects that can be criminally liable.

In criminal law,it is a principle that stated "no crimes without guilty" in the Dutch was known as "geen straf zonder schuld". This principle can be seen in the Article 6 paragraph (2) Law Number 14 Year 1970 on the Primary Law of Judicial Power, In criminal law there is a principle of no criminal without error which is known in the Dutch language as "geen straf zonder schuld". We can see this principle in article 6 paragraph (2) of Law Number 14 Year 1970 concerning the Basic Provisions of Judicial Power, then after the amendment to the 1945 Constitution was replaced by Law Number 4 year 2004 concerning Judicial Power and finally which is still valid until now in Law Number 49 Year 2009 concerning Judicial Power. In the official explanation of the article, that provision is solely to guarantee human rights that are protected in the state based on Pancasila.

\section{METHOD}

The research used is normative legal research; the applied approaches were the statute approach and conceptual approach. Sources of legal material in this study are sourced from the results of library research by reading books, writings, and legislation related to research, and legal materials used are primary legal materials and secondary legal materials.

\section{ANALYSIS AND DISCUSSION}

\section{Law Politics of Corporate Responsibility in Indonesia Criminal Code}

In the Criminal Code (hereinafter referred to as the Criminal Code) applicable in Indonesia, the only perpetrators are human beings. The provisions regarding this matter are caused by the

\footnotetext{
${ }^{1}$ Muladi and Dwidja Priyatno. (2013). Pertanggungjawaban Pidana Korporasi. Jakarta: Kencana Prenada media Group, p. 1

${ }^{2}$ Ibid. p. 2

${ }^{3}$ Ibid. p 5
} 
Criminal Code itself, which says so because at that time it was influenced by the writings of some scholars, namely von SAVIGNY and von FEUERBACH. The provisions in the Criminal Code that say only humans can commit a crime are Article 59 which reads: "in cases where due to violations the criminal is determined against the management, members of the governing body or commissioners, the management, members of the governing body or commissioners who apparently not meddling did not be convicted"4

It has been justified by the explanation in the Memory van Toelichting regarding the formation of Article 59 of the Criminal Code stated that: "only human beings can commit a criminal act. The presumption that a legal entity can act like a human does not apply in the field of criminal law." 5

The sentencing of legal entities, in the past centuries, is already a common thing. However, after being influenced by the writings of several writers, such as von SAVIGNY and von FEUERBACH, then there arose a new understanding, which said that a gemeenschap or a society could not commit a crime. At the time of the Criminal Code was established, this understanding was common in the Netherlands. For this reason, we are not surprised why the explanation in the Memory van Toelichting of Article 59 of the Criminal Code reads as stated above. $^{6}$

Different from the Netherlands, which stipulates that corporations can be subject to criminal offenses and can be directly accounted as criminals (Law June 23, 1976, Article 51) is changed to 1 . Criminal acts can be committed by humans nature and legal entity. 2 . If a criminal act is carried out by a legal entity, a criminal charge can be made, and if deemed necessary it can be imposed with a criminal offense and the actions listed in the law against a. Legal entity; or $b$. Against those who rule to do that, likewise those who act as leaders carry out the prohibited act; or $\mathrm{c}$. As mentioned in $\mathrm{a}$ and $\mathrm{b}$ together. 3 . For the use of the remaining paragraphs to be equated as a legal entity: a company without the rights of a legal entity, a union, and a foundation.

As we know that the Indonesian Penal Code is a Dutch colonial legacy, which previously the Dutch Penal Code did not recognize the corporation as the subject of a criminal offense, but now as the authors mentioned above that in the Netherlands itself the provisions regarding it have been amended which the corporation can already be considered a subject of criminal offense that is in Article 51 WVS. Different to Indonesia, which still maintains the provisions of Article 59 of the Criminal Code (the former of Article 51 W.V.S ).

Considering this fact, for the future of Indonesia, it is necessary to reform the Dutch colonial legislation, both insofar as it updates the provisions regarding corporate responsibility in the Criminal Code and discriminatory national laws through legislation programs.

\section{Legal Politics of Corporate Responsibility in the Draft of Indonesia Criminal Code}

According to Soedarto, legal politics is the policy of the state through the state agencies that are authorized to set the desired regulations. The laws are expected to be used to express what is contained in society and to achieve what is aspired. ${ }^{7}$ In another book entitled "Explanation of Law and Criminal Law" Soedarto also mentioned that legal politics is an attempt to realize good regulations in accordance with the circumstances and situations at a time. ${ }^{8}$ Related to

\footnotetext{
${ }^{4}$ Soenarto Soerodibroto. (1982). KUHP \& KUHAP dilengkapi Jurisprudensi Mahkamah Agung dan Hoge Raad. Jakarta: Soenarto\&Assosiates, 1982. p. 44

${ }^{5}$ P.A.F.Lamintang. (2013). Dasar-Dasar Hukum Pidana Di Indonesia. Cetakan kelima. Bandung: PT Citra Aditya Bakti, p. 600.

${ }^{6}$ Ibid.

${ }^{7}$ Soedarto. (1983). Hukum Pidana dan Perkembangan Masyarakat dalam Kajian Hukum Pidana,Bandung: SinarBaru, p. 20.

${ }^{8}$ Soedarto. (1986). Hukum dan Hukum Pidana. Bandung: Alumni, p.151.
} 
the understanding of legal politics by Soedarto above, the government's efforts to make a legal policy will refer to conditions and situations that are in accordance with the needs of the community.

Corporations not only carry out activities to achieve their goals but in some cases, corporations have committed crimes. Corporate crime is a form of crime that afflicts almost all countries in the world, which causes widespread harm to society. The characteristics of corporate crime are different from other conventional crimes.

In general, there are several characteristics of corporate crime. First, the crime is difficult to detect (low visibility), it is usually covered by normal and routine work activities, involving professional expertise and complex organizational system. Second, the crime is very complex because it is always related to lies, fraud, and theft associated with something scientific, technological, financial, legal, organized, and involves many people and runs for years. Third, the occurrence of the spread of responsibility (diffusion of responsibility) is increasingly widespread due to organizational complexity. Fourth, the diffusion of victims is very broad (diffusion of victimization), such as pollution and fraud. Fifth, obstacles in detection and prosecution (detection and prosecution) as a result of unbalanced professionalism between law enforcement officials and criminals; Sixth, unclear rules that often lead to losses in law enforcement. ${ }^{9}$

The purpose of the corporation to continue to increase the benefits it receives results in frequent violations of the law. Corporations, whether in the form of a legal entity or not, have great authority in carrying out their activities. They often carry out activities that are contrary to applicable legal provisions, even causing victims to suffer losses. Many corporations have escaped the pursuit of the law, so corporate actions that are contrary to the law are increasingly widespread and difficult to control. Corporations easily eliminate evidence of crimes against the public, including intervene law enforcement officials. ${ }^{10}$

Considering these conditions or situations, the government, with its inherent authority can issue a legal policy to prevent and deal with the consequences that may result from criminal acts committed by corporations.

In the Criminal Code draft of 2004/2005, corporations are regulated in Articles 47 to 53. Based on Article 47, corporations are subject to criminal law, while Article 48 of the Criminal Code draft, a crime is carried out by the corporations if it carried out by persons that acting for and for the name of the corporation or in the interests of the corporation, based on work relations or based on other relationships within the scope of the corporation's business. Article 49 states, if a corporation commits a criminal act, criminal liability is imposed on the corporation and/ its management.

Article 50 stated acts that can be accounted for by the corporation if the act is carried out for and / or on behalf of the corporation, if the act is included in the scope of business as stipulated in the articles of association or other provisions. Article 51 of the Draft Criminal Code, the criminal liability of the management of the corporation is limited as long as the management has a functional position in the structure of the corporate organization. Article 52 paragraph (1), in considering a criminal decision, it must be taking into account sanction on a corporation. Article 53 states, the reasons for forgiveness and justification submitted by makers acting for

\footnotetext{
${ }_{9}^{9}$ Rony Saputra. (Desember 2015). "Pertanggungjawaban Pidana Korporasi Dalam Tindak Pidana Korupsi (Bentuk Tindak Pidana Korupsi Yang Merugikan Keuangan Negara Terutama Terkait Dengan Pasal 2 Ayat (1) UU PTPK)". Jurnal Cita Hukum. Vol. II, No. 2, p 274-275.

${ }^{10}$ Taun. (Agustus 2018). "Pertanggungjawaban Pidana Korporasi Dalam Tindak Pidana Ketenagakerjaan," Jurnal IUS, VOL VI, No. 2, p. 236-237.
} 
and / or on behalf of the corporation, may be submitted by the corporation as long as these reasons are directly related to the actions charged with the corporation.

However, not all crimes can be carried out the same responsibility between individuals and Corporations as legal subjects, Barda Nawawi Arif, made several exceptions, including

1. In cases which by nature cannot be conducted by corporations, for example, bigamy, rape, and perjury;

2. In cases where the only crime that can be imposed may not be imposed on a corporation such as imprisonment or death penalty. ${ }^{11}$

According to Andi Hamzah, related to the offenses of what can be conducted by the corporation. The corporation cannot be convicted. Therefore if it is determined that the corporation can commit certain offenses, the offense must have an alternative fine criminal threat. If the corporation can be charged for all types of offenses, all offense formulations in the Criminal Code must have an alternative criminal fine as regulated in the Dutch W.V.S. ${ }^{12}$

Regarding the types of criminal acts that are considered carried out by corporations. According to de Maglie, that some countries do not differentiate between these types of criminal acts, in the sense that any criminal act committed by a person is considered to be also carried out by a corporation. This approach is adopted by several countries such as Australia, Canada, the Netherlands. However, there are also countries, for example France, which state that corporations are only responsible if they are explicitly stated in the statutory regulations, which are the basis of criminal punishment. The US make a list (in the U.S Sentencing Guidelines) which contains what crimes that can be held accountable to corporations. ${ }^{13}$

\section{Corporate Responsibility in other Indonesia's Laws and Regulations}

According to Indonesian laws and regulations, corporations can be subject to criminal acts and can be held accountable for their actions governed by specific laws, including:

\section{Law Number 7 Drt. 1955 on the Investigation, Prosecution and Judicial of Economic Crimes}

Corporations can be a subject of criminal acts and able to hold legal responsibility as regulated in Law No. 7 Drt 1955 concerning the Investigation, Prosecution, and Judgment of Economic Crimes. Article 15 of Law No. 7 Drt 1955 concerning the Investigation, Prosecution and Judgment of Economic Crimes, which stated:

"whether an economic criminal offense is carried out by or on behalf of a legal entity, a corporation, an association of or foundations, the criminal prosecution is carried out and criminal penalties and disciplinary actions are imposed against the legal entity of the company, association or foundation, whether against those who give orders to commit these economic crimes or who act as leaders in the act or omission, or both. "

The reasons for the conviction of a corporation are explained in the explanation in Article 15 above, which state:

"Article 15 stipulates that penalties or actions may also be imposed on legal entities, corporations, unions, and foundations. In economic criminal law the regulation is urgently needed because many economic criminal acts are carried out by these bodies. Modern criminal law has recognized the notion that punishment can be pronounced against a legal entity".

\footnotetext{
${ }^{11}$ Yudi Krismen. "Pertanggungjawaban Pidana Korporasi Dalam kejahatan Ekonomi”. Jurnal Imu Hukum, VOL 4. No. 1. p. 145

${ }^{12}$ Andi Hamzah. (1989). Tanggung Jawab Korporasi dalam Tindak Pidana Lingkungan Hidup. Jakarta: Kantor meneg LKH. p. 34.

${ }_{13}$ Andri G. Wibisana. (April-Juni 2016). "Kejahatan Lingkungan Oleh Korporasi: Mencari Bentuk Pertanggungjawaban Korporasi dan Pemimpin/Pengurus Korporasi Untuk Kejahatan Lingkungan Di Indonesia". Jurnal Hukum \& Pembangunan, Vol 46, No. 2. p 153.
} 
The Economic Criminal Act also regulates who can be held responsible in a trial, or who represents a legal entity at a trial if a legal entity commits the crime? Concerning this matter is regulated in Article 15 paragraph (3), which reads:

"If a criminal complaint charges against a legal entity, a corporation, a union of persons or foundations, then the legal entity, company, association or foundation at the time of the prosecution is represented by an executive or, if there are more than one executive, by one of the management of them. Judges can order an administrator to appear before him in court, and can also order that the administrator be brought before a judge. "

Article 7,until Article 9 of Law No. 7 of 1955 regulates the sanctions that can be imposed on corporations, namely: a). Sanctions that can be imposed are additional crimes in the form of the closure of all or a part of the law firm, in which an economic crime is committed, in one year (Article 7 paragraph (1) letter b). b). Confiscation of tangible and intangible items including the company of the convicted person originating from economic crimes (Article 7 paragraph (1) letter c jo. Letter d). c). Revocation of all or part of certain rights or deletion of all or part of certain profits, which have been or can be given to the convicted by the Government in connection with the company, for a period of two years (Article 7 paragraph (1) letter e). d). Announcement of the judge's decision (Article 7 paragraph (1) letter f). e). Disciplinary actions, such as putting the condemned company under his lease, obliging the payment of bail, obliging to pay a sum of money as a revocation of profits, obliging to do what was neglected without rights, negating what was done without rights, and performing services to repair the consequences the consequences of each other, all at the expense of the convicted person, just the judge does not determine otherwise (Article 8 letters a, b, c). f). Criminal fines, because according to Article 9 it is said that the imposition of a criminal code of conduct in Article 8 must be accompanied by criminal sanctions, and appropriate criminal sanctions can be imposed on corporations is criminal fines.

\section{Law Number 32 Year 2009 on the Protection and Management of Environment}

Article 116 paragraph (1) regulates, a criminal offense is committed by a corporation, which reads: if an environmental criminal offense was committed by, for, or on behalf of a business entity, criminal prosecution and criminal sanctions are imposed on: a). business entity; and/or; b). the person who gives the order to commit the crime or the person who acts as the leader of the activity in the crime

In an environmental crime committed by a corporation if an authorized management represents the trial per the legislation as a functional offender (Article 118). Corporations may be subject to additional criminal or disciplinary action in the form of:

a. Deprivation of profits derived from criminal acts;

b. The closure of all or part of the place of business and/or activity;

c. Improvement due to criminal acts;

d. The obligation to do what was neglected without rights; and/or

e. Placement of the company under the maximum period of 3 (three) years.

\section{Law Number 8 Year 1999 on Consumer Protection}

Perpetrators of criminal acts in consumer protection laws are referred to as "Business Actors". Article 1 number (3) explains that Business Actors is defined as any individual or business entity, both in the form of legal entity or non-legal entity established and domicile or 
carrying out activities within the jurisdiction of the Republic of Indonesiathrough an agreement to conduct business activities in various economic fields.

Criminal sanctions can be applied to business actors and/or their management (Article 61), criminal sanctions that can be imposed on "Business Actors" are criminal fines (Article 62), so these criminal sanctions are imposed both on individuals and business entities/legal entities. Then regarding additional crimes regulated in Article 63. Additional Crimes in the form of: a). Confiscation of certain goods; b). Announcement of the judge's decision; c). Payment of compensation; d). Orders to stop certain activities that cause consumer losses; e). Obligation to withdraw goods from circulation, or $\mathrm{f}$ ). Revocation of business licenses.

After talking a lot about how a corporation can become a criminal and can also be held accountable for its actions in the special law above, in this last part the author will discuss issues that are often debated by legal experts about the question of how to determine mistakes in a corporation. According to Suprapto, Van Bemmelen, as well as Remmelink, acknowledged that corporations can still have errors with construction that the mistakes were taken from the management or members of the directors. ${ }^{14}$

\section{CONCLUSION}

The subject of a criminal offense in the criminal law book is limited to individuals. So if a crime occurs in a corporation, then the crime is considered to be committed by the corporation's management. Such provisions were obtained because the compilers of the Criminal Code were previously influenced by the principle of societies delinquere nonpotest or universities delinquere nonpotest. Speaking about the reformulation of the corporate criminal liability system is inseparable from legal politics, which with legal politics is the government's attempt to guarantee its citizens in achieving social welfare, including the enactment or improvement of laws in various fields as well as reformulation of the provisions regarding corporate criminal liability. Corporations can become perpetrators of crime and can be accounted for by their actions governed by various special laws. Then in terms of determining mistakes in the corporation. That the corporation can still have errors with the construction that the mistakes are taken from the management or members of the directors.

\section{BIBLIOGRAPHY}

\section{Books}

Andi Hamzah.(2014). Asas-Asas Hukum Pidan. Jakarta: Rineka Cipta.

Andi Hamzah. (1989). Tanggung Jawab Korporasi dalam Tindak Pidana Lingkungan Hidup. Jakarta: Kantor meneg LKH.

Barda Nawawi Arif. (1990). Perbandingan Hukum Pidana. Jakarta: Rajawali Perss.

Muladi dan Dwidja Priyatno. (2013). Pertanggungjawaban Pidana Korporasi. Jakarta: Kencana Prenada media Group.

P.A.F.Lamintang. (2013). Dasar-Dasar Hukum Pidana Di Indonesia. Cetakan kelima. Bandung : PT Citra Aditya Bakti.

Soenarto Soerodibroto. (1982). KUHP \& KUHAP dilengkapi Jurisprudensi Mahkamah Agung dan Hoge Raad. Jakarta: Soenarto \& Assosiates.

Soedarto. (1983). Hukum Pidana dan Perkembangan Masyarakat dalam Kajian Hukum

\footnotetext{
${ }^{14}$ Andi Hamzah. (2014). Asas-Asas Hukum Pidana. Jakarta: Rineka Cipta, p. 106
} 
Pidana. Bandung: Sinar Baru.

Soedarto.(1986). Hukum dan Hukum Pidana. Bandung: Alumni.

Sudarto. (1987). Pemidanaan, Pidana dan Tindakan dalam "masalah-masalah Hukum”. Semarang: FH-UNDIP.

\section{Journal articles}

Andri G. Wibisana. (April-Juni 2016), "Kejahatan Lingkungan Oleh Korporasi: Mencari Bentuk Pertanggungjawaban Korporasi dan Pemimpin/Pengurus Korporasi Untuk Kejahatan Lingkungan Di Indonesia”. Jurnal Hukum \& Pembangunan , 46, No. 2.

Rony Saputra. (Desember 2015). "Pertanggungjawaban Pidana Korporasi Dalam Tindak Pidana Korupsi (Bentuk Tindak Pidana Korupsi Yang Merugikan Keuangan Negara Terutama Terkait Dengan Pasal 2 Ayat (1) UU PTPK)”. Jurnal Cita Hukum. Vol. II No. 2.

Taun. (Agustus 2018). "Pertanggungjawaban Pidana Korporasi Dalam Tindak Pidana Ketenagakerjaan," Jurnal IUS. VOL VI. No. 2.

Yudi Krismen. "Pertanggungjawaban Pidana Korporasi Dalam kejahatan Ekonomi”. Jurnal Imu Hukum, VOL 4. No. 1. 